\title{
TOURISM IN DEVELOPMENT OF SOUTH PRAGA DISTRICT OF WARSAW
}

\author{
W. Banasik \\ University of Physical Education \\ Warsaw, Poland
}

\begin{abstract}
This article is about one of the Warsaw's district, South Praga. It aims at determine the essence and the tourist development's perspectives in the district. To this end, pilot studies were performed in the whole South Praga. The group of respondents consisted of District Department employees and the councilors, tourism administrators represented by restaurants' managers and the employees of the Centre of Tourism Promotion and Culture. The questions were about the tourist attractiveness of South Praga, taking into consideration its' listed buildings and other elements. The questions were asked in order to get to know the opinion of the people who, because of their jobs, take interest in the tourist development in South Praga.
\end{abstract}

Key words: Warsaw South Praga, tourism in municipality, Saska Kępa.

Self-government is a term widely associated with local government. It conveys all the activities carried out in order to solve problems by the ones directly involved in the given issue.

A local government is a kind of office setting out a legal framework for citizens' selfgovernment. As a form of public administration it is characterized by a specific feature, namely, it is done by a local community group, whose functioning is based on the principle of equality of its members.

Self-government is a form of organization of a given social group, which can thus decide on the relevant to them issues at the limits of the law, acting directly or through democratically elected representatives. Local government is a type of self-government which is based on the relationships resulting from the common area of residence [14]. Other, equally important forms of self-government are economic self-government and professional self-government.

As the above definition suggests a local government participate in exercising public authority and is its important element. It performs a part of public functions defined by the law, on its own behalf and under its own responsibility.

Local government determines the need for local regulating and managing public affairs for the good of a local community. Implementing the idea of local development is related to the positive socio-economic transformation, development of the productive forces to meet the needs of a local community [17]. The concept of local self-government in its three-level model is a mandatory union of residents of municipalities, counties and voivodeships, created for carrying out the local tasks by municipalities and counties as well as regional tasks by voivodeships, in order to ensure the development of the area and meet collective needs (in the field of public usability) of the population of the area [5]. 
In light of the literature it can be stated that the most important aspect is, however, the local government as a community of citizens living in the area, the region, taking action on its own responsibility in order to implement local public tasks.

\section{Nature and organizational structure of local self-government}

The basis for the separation of the local government is territorial association. A resident's relationship with a given unit of local government is based almost solely on the fact that one resides in the territory. In order to determine the nature of local government, it is necessary to name its object and its subject, as well as a way of performing a function of national administration.

The subject of local government is a society living in a specific area, it is united in a community that seeks to carry out tasks in the field of public administration on its own behalf and assuming the responsibility for it. [10]

According to the Constitution of 1997 the territorial organization of the Republic of Poland shall ensure the decentralization of public power. These administrative diffusion means transferring in accordance with the law, public-legal responsibility for the execution of public duties on independent legal entities, the administrative offices that are not part of a centralized government.

With decentralization, there is no hierarchical subordination of the bodies or the personal or in rem, lower levels of authority have the right to set up self-reliance and independence, subject only to the supervision exercised by the criterion of legality [6]. Local government participate in the exercise of public authority [4], moreover all the inhabitants of basic territorial division are a self-governing community under the law [4].

Generally characterizing the subject of local government one should mention that it is created by a self-government community, whose member one becomes involuntarily, due to residing the area.

The subject of local government is the state administration, which is directly related to the implementation of the executive functions of the state. In terms of public tasks in the field of public administration principle of decentralization is essential, whereby local associations carry out their tasks independently [11]. Currently in Poland according to the law passed by parliament in 1998, structure of three-levels local government is in force, it is based on the new administrative division of the country. Basic units of local government division of the country are: municipality, county and voivoideship [8].

Residents of municipalities form a self-governing community under the law. Whenever the Act refers to a municipality, it means self-government community and the relevant territory [15].

This means that the basic unit is not the office of municipality itself, but the local society associated with each other by the same place of residence as well as common issues directly related to them as members of this group.

Another level, the second in the classification of units in Polish territorial division is a county. County - a local self government community and relevant area on which the county residents form a local self government community under the law [10]. As you can see the definition of a county is a little different from the one presenting the concept of municipality in terms of people and territory. 
Municipality being the basis in the structure of territorial division is a part of a county, which is its higher level. To put it more precisely the relationship of several municipalities, defined as local community creates one large society living in the same region, linked by the interests of life. Voivodeship in accordance with the law means both units of local government (regional self-governing community) as well as the biggest unit of territorial division for the purpose of public administration. Elements constituting voivodeship are specific local community and specific area of the country [9].

Accordingly, the voivodeship is the highest unit of local government three-level model. In addition, counties that are components of the voivodeshipss are not dependent on them, as the voivodeships are not superior to lower units of territorial division. Local government, as a union of residents of the area, has a primary responsibility of implementing tasks that meet public needs of a community. As stated in the Constitution of the Republic of Poland duties have been split into internal tasks and commissioned ones.

The division of tasks of local government into internal and commissioned derives from differences that occur in the process of their implementation. A unit performs internal tasks basing on their own financial resources, and commissioned ones after government administration ensures their financing. The responsibility for implementation of the first group of tasks is directly held by a local self-government while the tasks of the second group - by state government and indirectly by local government [9].

Division of tasks into internal and commissioned tasks exists in relation to the tasks of municipality [7]. Their scope is defined in the Local Government Act of 1990. According to it municipality performs all tasks of a local nature, that are not assigned by law to be other entities' responsibility.

Internal tasks of municipality may be mandatory or voluntary, those obligations are supposed to satisfy convergent needs of social groups that create a self-governing community.

Internal tasks of municipality include a number of issues related to spatial order, land management and environmental protection, municipal roads, streets, water supply systems, sewerage, supply of electricity and heating as well as local public transport, health care, social assistance, including nursing homes, municipal housing, education, culture, including municipal libraries, other institutions promoting culture, green areas and trees, municipal cemeteries, public order and fire protection, providing social, medical and legal assistance to pregnant women [18].

However, the tasks of municipality in relation to tourism include the protection of monuments of cultural heritage, promotion of municipality, tasks concerning physical education, including recreational areas and sports facilities, coordination of tourism programming, the municipality's internal responsibilities under the Act on tourist services, local information (marking streets and tourist sites), creating basis for the development of tourism (including finding budget). Classification of the above mentioned tasks according to the provisions of the Local Government Act and the Act on Tourist Services.

In order to fulfill internal tasks municipality carries out activities with self-government bodies of this unit as well as in the form of companies, institutions, such as public health care, libraries, schools, community centers, etc.

Execution of the tasks may not take place without adequate funding. 
When it comes to internal tasks, municipality uses its own financial resources. Often municipality self-income level testifies to the degree of a task fulfillment to great extent. However, the actions taken in the fulfillment of its tasks can get some funding.

Own resources that will allow the municipality to perform these tasks are derived from municipal taxes, shares in taxes from the state budget, the revenue the municipality property brings, grants from the state, the economic activities carried out by the municipality, received donations, etc. [16].

\section{Pilot study}

The basis for the organization when planning the study is to determine a problem and a definition of given terms. This means that answer to a question about which objects and phenomena we want to make our statements about, and what reasons underlie our actions and what we want to achieve [3]? The main goal of scientific study is to gain knowledge which is at most definite, sure, general, simple, with a maximum information content [13].

Problem or research problems are simply questions that we seek answers to during our pilot studies [2]. Research goal of this article reads as the role of tourism in the development of South Praga municipality was developed on the basis of minor "research purposes", research problems. They are as follows:

- Which South Praga tourist sights are considered its landmark?

- Does South Praga offer a wide range of events of different nature (cultural, entertainment, sports) in respondents' opinion?

- Which elements of natural environment are the most attractive according to the respondents?

- How do respondents evaluate the promotion and information of the district?

- Which of the residential district of South Praga is the most attractive according to respondents?

- How do respondents assess tourist services available in the area?

- Will the upcoming 2012 UEFA European Football Championship help create a new image of South Praga?

- What is the opinion of the respondents on how to increase the touristic attractiveness of the district in its present condition?

The next stage in the preparations for the conduct of the research is to determine a hypothesis or hypotheses. Hypothesis is the sentence describing a relationship between phenomena (events, conditions, qualities, etc.), whose logic value is checked in empirical, scientific research [1].

The hypotheses of this study are:

- Is South Praga South a place of tourism development now?

- Is the level of tourist services offered in the South Praga district satisfactory?

- Does South Praga have prospects for developing touristic attractiveness?

Overally, the hypothesis is a statement assuming the existence of possible relationships between at least two variables. What is important is the fact that the assumption as a hypothesis is used to explain for example a phenomenon. When formulating hypothesis one must assume that the links contained in it are possible to study, what would verification 
of the presence of given relationships.

Pilot studies were performed at the end of November 2011, in Warsaw. The exact area of study was dependent on the selected groups within which the interviews were conducted.

The study was conducted on a group of 12 people. Among the population participating in the study there are 4 subgroups, and in each of them there are 3 people. The first subgroup are the employees of the Office of South Praga district. The next sub-group are councillors form South Praga district. The third formation is formed by administrators of tourism and specifically catering, represented by managers of restaurants located in Saska Kepa. Last subgroup consists of employees of local cultural institutions, which is the District Centre for the Promotion of Tourism and Culture.

In general the population taking part in the study, taking into account all the sub-groups, consisted of 8 men and 4 women. The majority of the population was people aged $31-40$ years old, with higher education, residing in the district of South Praga.

People from each subgroup participated in the study respectively in their workplace. In the case of the workers of the District Office study took place at the premises of this institution, as well as in the subgroup of administrators - in the restaurant and in the subgroup of members of the Centre for the Promotion of Tourism and Culture - in the building of the institution. The interviews were conducted by means of a questionnaire and interview recorder. The questionnaire consists of eight open-ended questions concerning the possibility of the development of South Praga district in the area of tourism. Each person examined, regardless of the sup-group they belonged to, answered in person, orally, the same questions included in the interview questionnaire. Interviews were conducted without the presence of a third party.

\section{Conclusions drawn from the results when compared to overall data [19]}

Answering the first question of the interview questionnaire, respondents gave the highest percentage of votes in the number of $33 \%$ for religious buildings as the most representative monuments in South Praga in their opinion. Historic 'Grochowski Gates' (Rogatki Grochowskie) received 19\% of the votes time taking second place at the same. Thus, in the opinion of the respondents they are one of the most important objects in the map of the area, and are its landmark. Part of the respondents associate South Praga also with Wedel Chocolate Factory, which was granted $8 \%$ of the responses. In addition, respondents also recognized the National Stadium and Park Skaryszewski as a place identified with the district for giving them $6 \%$ of the votes. The attention of the surveyed is also attracted by facilities such as Poniatowski Bridge, the Monument of Agnieszka Osiecka and Francuska Street. Each of the three sites got the same and also the least amount of voices, only $3 \%$. This result proves that the objects that got a minor number of votes in relation to the rest are in respondents' opinion less recognizable and characteristic for the district.

Respondents' answers to the second question of the questionnaire are varied. The results show that 4 out of 12 people surveyed do not consider the district offer of events as a diverse and interesting one, in their opinion, it is on average level. It was the most popular opinion given by respondents. Next 3 people reported strongly that the offer proposed by the district is not wide. The same number of the survey participants, that is three, said that 
South Praga offers a wide range of events. The smallest number of people in the surveyed group, only 2, consider an offer of cultural entertainment, sports events, prepared by the district, to be as wide as the funding level allows.

The third question concerned the elements of the natural environment in South Praga, that in the opinion of the respondents are the most attractive. Respondents gave the greatest number of their votes, 33\%, for Skaryszewski Park. The lake Balaton received not much less recognition in the opinion of the respondents, the difference being only $2 \%$, it got $31 \%$ of declarations. third place, with $11 \%$ of votes of the respondents was given to Kamionkowskie Lake (Jeziorko Kamionkowskie). In addition, the group also mentioned Exhibition Channel (Kanał Wystawowy) and Olszynka Grochowska reserve giving them the same number of votes, $10 \%$ for each. Among interesting nature values, $6 \%$ of respondents mentioned Park Obwodu AK, and the remaining 3\% of the votes were admitted to Balaton Park.

Another question in the questionnaire showed how respondents assess the district promotion and information. Opinions are divided in the majority, but more than half of the group, nearly $70 \%$ said that the efforts made in this field are practically visible on websites dedicated to South Praga and through the Internet itself. This is according to the respondents due to the present time rule assuming that the Internet is the most common source of information. When it comes to folders, prints and brochures about the area, opinions are different. Few people recognize any publication on the promotion and information of South Praga, but if they are visible they are published sporadically when organizing major events in the area. The issue of funding plays an important role according to the group because the financial resources level determines the amount of performed activities aiming at the development and promotion of South Praga and their scale, within the district itself and in other districts of Warsaw.

The results obtained in the fifth question show little variation in the declarations. According to more than half of the population, $75 \%$ of respondents said Saska Kepa is the most attractive. The remaining part of the group mentioned Gocław (17\% votes) and Grochów, (the smallest percentage of respondents, only $8 \%$ )

Opinions on tourist services offered by the district among the respondents can be assessed to be consistent, with no significant differences. According to the majority of the surveyed population generally these services can be assessed to be at a good level. Respondents showed the opinions on each of the subgroups. Among touristic services, the respondents definitely recognized recreational and catering base of South Praga as rather satisfactory, taking into account the diversity of facilities in terms of cuisine types and standards, whereas when it comes to leisure facilities a number of objects were noticed: pools, squares, parks, newly-established pitches for team games, and other infrastructure enabling practicing a wide variety of recreation. Transport and good transport links are of great importance to them.

A negative assessment of the accommodation base was expressed by the respondents. In their opinion, the base almost does not exist in practice. Accommodation is offered by a small number of facilities that does not arouse positive reviews. Respondents mentioned lack of offers aimed at visitors from outside, services for tourists, an organization associated with sightseeing the area as the main flaws of touristic services. But according to the 
respondents it is definitely accommodation base of South Praga that should be enriched and enlarged in the first place.

The next question in the questionnaire allowed to get to know the respondents opinion on the possibility of creating a different image of the area through activities related to the 2012 UEFA European Football Championship. The result shows that $67 \%$ of the population surveyed agrees with the statement that Euro 2012 will create a new image of South Praga. Some of the respondents who gave this response, said that for some time that preparation for the championships have been undertaken, thus creating a new look of South Praga. Works improving the transport links and struggle with the renovation of some facilities were noticed. The remaining $33 \%$ of the respondents felt that this event will have no impact on change in perceptions of the district (Figure 25). One of the respondents stated that the sports event shouldn't be linked to activities changing the image of South Praga, as actions will be related to the preparation of the necessary infrastructure for the championship rather than the development of the district.

The final, and at the same time last question concerned the respondents' assessment of development opportunities for rising tourist attractiveness of the district in its current state. Opinions are divided, the smallest group of respondents admit such a possibility, since South Praga has a strong and diverse foundation for the development and emphasizing their strengths in the field of tourism. According to this part of the surveyed:

- $\quad$ They are interesting places and attractions here.

- $\quad$ South Praga is building its new image as a sports and cultural district.

- We break with the image of a dangerous and run-down neighborhood.

- $\quad$ There are a number of programs such as the revitalization of squares, parks. Historic buildings will be restored.

- $\quad$ The new stadium will attract with its wide sports offer, mass events such as concerts, competitions will also be organized at the stadium.

Three respondents have quite a contrary opinion, as they believe that what prevents development of tourism in the district is:

- Insufficient promotion of district

- Lack of adequate accommodation base

- Monuments and natural elements including parks being all neglected

- No cycling connections with other districts of Warsaw.

The above mentioned flaws and weaknesses in the field of the present touristic preparation, according to the part of the respondents, do not see perspecives of improving attractiveness of South Praga.

Another group of respondents, 9 people see prospects for development of tourist attractiveness of South Praga, provided adequate funding is ensured in order to allow the improvement of the monuments conditions, other resources, as well as promotion and tourist information. The respondents claim Range of tourist progress depends on the financial resources, which would be used for this purpose.

The respondents' suggestions for allocation of funds for the development of tourist attractiveness of South Praga South are as follows:

- Definitely promotion, dedicating larger funds for this purpose.

- Much more support for the revitalization of facilities such as Skaryszewski park 
and Olszynka Grochowska reserve.

- In addition, put devastated infrastructure by the Vistula River in order, the National Stadium itself will not change the situation.

To sum up all the respondents; opinions and suggestions of the opportunities and barriers for the development of tourist attractiveness of South Praga what should be improved first of all is the condition of monuments that will attract people with their new image. Similar efforts should be made to revitalize parks and Olszynka Grochowska Reserve. The management of Vistula shore and sports facilities need to be improved, as their image is disgusting.

In addition, the number of accommodation facilities must be increased in the area, information and promotional activities need to be improved as well as suitable investors should be found in order to obtain the necessary financial resources for tourism development of South Praga, as this district has undoubtedly great potential for progress.

\section{Ending}

Local government defines the need for standardization and regulation of public affairs for the good of the local community. Relationship of residents is created to perform tasks on a local level by municipalities, counties and tasks of regional profile conducted by voivodeships.

Local government operates independently and has its own structure, the units forming it, and these, in turn, have the primary responsibility in the form of implementation of tasks aimed at meeting the public needs of the community. In order to fulfill these responsibilities, adequate bodies in charge of the assigned tasks are established within each level of the division.

In the current structure of the territorial division there can be auxiliary units within each level, for example village, districts, neighborhoods.

In the case of Warsaw, the capital city of Masovian voivodeship, as well as in other cities and towns, there are division units called districts. One of the districts of Warsaw is South Praga, located on the right bank of the Vistula River, it consists of six smaller areas, among them: Gocław, Grochów Kamionek, Olszynka Grochowska, Saska Kepa and Gocławek.

Location of the district on the bank of the Vistula River and many of its elements including tourism make it attractive area. South Praga creates its image with large natural environment resources. Nature here is represented by parks, Olszynka Grochowska reserve, natural monuments and reservoirs. Undoubtedly, the most popular part of the natural area is Park Skaryszewski with rich vegetation, Kamionkowski lake and, interesting setting of extensive park complex with various recreational and "cultural" (amphitheater) infrastructure. All of above listed items and any individual one may be of interest to tourists.

In addition to natural resources the district offers numerous monuments, largely sacred architecture represented by a number of churches. Furthermore, among historic buildings one can mention Manor Grochowski, places connected with the history of the area with monuments commemorating them, cemeteries. The attractiveness not related to nature is enhanced by cultural facilities engaged in activities aimed at developing 
the district and building its entertainment offer linked to the culture. These institutions dynamically build this offer dealing with, inter alia, the organization of concerts, historical performances, workshops, enriching and diversifying the attractiveness of the area for visitors and residents.

Conducting research among several groups related to the district made it possible to analyze the place of tourism and its role in the development of South Praga district of Warsaw. Research shows respondents' opinions about the attractiveness of the area in terms of its values and the possibility of their use, as well as assessment of future prospects in this direction. According to the surveyed people the area has a great potential for tourism, but it is not possible to be taken advantage of in the right way because of the lack of funds needed to eliminate obstacles constraining development. According to the respondents' opinion the condition of monuments has to be improved, negligence in the promotion and information should be eliminated and the range of accommodation needs to be expanded. More than half of the study population states that the 2012 Euro Championships, which will take place, among others, at the National Stadium located in the district, will be an opportunity to improve the current state of South Prague.

\section{LIST OF REFERENCES}

1. Hajduk E., Hipoteza w badaniach pedagogicznych, Wyższa Szkoła Pedagogiczna im. Tadeusza Kotarbińskiego, Zielona Góra 1998, s. 52

2. Jankowski K. W. , Lenartowicz M., Metodologia badań..., op. Cit., 29

3. Jankowski K. W., Lenartowicz M., Metodologia badań empirycznych,Akademia Wychowania Fizycznego Warszawa 2007, s. 29

4. Konstytucja RP z dn. 2 kwietnia 1997 r., art. 16 ust. 2

5. Korzeniowska A., ABC samorządu terytorialnego, Oficyna Wydawnicza Branta, Wyższa Szkoła Administracji Publicznej w Łodzi 2004, s. 26

6. Korzeniowska A., ABC samorządu..., op. cit., s. 36

7. Korzeniowska A., ABC samorządu..., op. cit., s. 32

8. Korzeniowska A., ABC samorządu..., op. cit., s. 37

9. Korzeniowska A., ABC samorządu..., op. cit., s. 38

10. Oleksiewicz I., Pomykata M. (red.), Znaczenie i funkcjonowanie..., op. cit., s. 81

11. Oleksiewicz I., Pomykała M. (red.), Znaczenie i funkcjonowanie samorządu w Polsce, Oficyna Wydawnicza Politechniki Rzeszowskiej, Rzeszów 2010, s. 79

12. Oleksiewicz I., Pomykała M. (red.), Znaczenie i funkcjonowanie..., op. cit., s. 82

13. Pilch T., Zasady badań pedagogicznych, Wydawnictwo Żak, Warszawa 1995, s. 9

14. Smutek Z., Maleska J., Surmacz. B., Wiedza o społeczeństwie zakres podstawowy, Wydawnictwo Pedagogiczne OPERON, Gdynia 2003, s. 148

15. Ustawa z dnia 8 marca 1990 r. o samorządzie gminnym, art.. 1

16. Wronkowska S, Zmierczak M. (red.), Kompendium wiedzy..., op. cit., s. 341

17. Wykrętowicz S. (red.), Samorząd w Polsce- istota, formy, zadania" Wydanie trzecie uaktualnione, Wydawnictwo Wyższej Szkoły Bankowej, Poznań 2004, s. 96

18. Wykrętowicz S. (red.), Samorząd w Polsce..., op. cit., s. 71

19. Ze względu na objętość artykułu nie przedstawiono charakterystyki badanego obszaru oraz wyniki tylko końcowe i w postaci opisowej. 


\title{
РОЗВИТОК ТУРИЗМУ У ВАРШАВСЬКОМУ РАЙОНІ ПІВДЕННА ПРАГА
}

\author{
В. Банасік \\ Університет фізичної культури \\ Варшава, Польщса
}

\begin{abstract}
Ця стаття про один з районів Варшави Південну Прагу. Вона спрямована на визначення сутності та перспективи розвитку туризму в районі. Для цього дослідження використано групу респондентів, яка складалася з районного відділу співробітників і радників туризму, адміністраторів ресторанів, керівників і співробітників Центру розвитку туризму і культури. Питання були про туристичну привабливість Південної Праги, беручи до уваги його туристичні ресурси. Питання були задані для того, щоб дізнатися думку людей, які в силу своєї роботи, виявляють інтерес у розвитку туризму в Південній Празі.

Ключові слова: Варшава, Південна Прага, туризм в муніципалітеті.
\end{abstract}

\section{РАЗВИТИЕ ТУРИЗМА В ВАРШАВСКОМ РАЙОНЕ ЮЖНАЯ ПРАГА}

\author{
В. Банасик \\ Университет физической культуры \\ Варшава, Польша
}

Эта статья об одном из районов Варшавы Южную Прагу. Она направлена на определение сущности и перспективы развития туризма в районе. Для этого исследования использованы группу респондентов, состоящая из районного отдела сотрудников и советников туризма, администраторов ресторанов, руководителей и сотрудников Центра развития туризма и культуры. Вопросы были о туристической привлекательности Южной Праги, считая его туристические ресурсы. Вопросы были заданы для того, чтобы узнать мнение людей, которые в силу своей работы, проявляют интерес в развитии туризма в Южной Праге.

Ключевые слова: Варшава, Южная Прага, туризм в муниципалитете. 